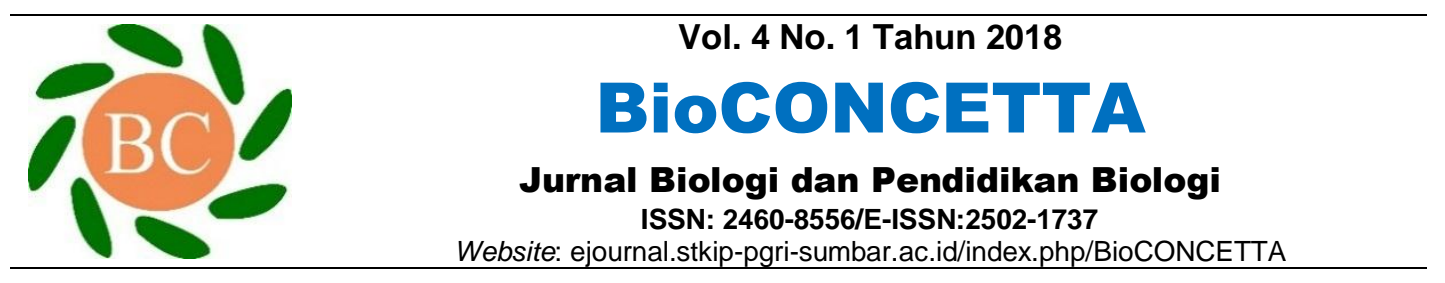

\title{
Hubungan Antara Nilai Kompetensi Pengetahuan Biologi Umum dengan Taksonomi Invertebrata
}

\author{
Nurhadi*, Febri Yanti dan Mimin Mardhiah Zural \\ Program Studi Pendidikan Biologi STKIP PGRI Sumatera Barat \\ Jl. Gunung Pangilun Padang, Sumatera Barat (25137) Indonesia \\ E-mail: plg.nurhadi@yahoo.com
}

\begin{tabular}{l} 
Info Artikel \\
\hline Sejarah Artikel \\
Diterima: \\
4 Juli 2018 \\
Disetujui: \\
30 Agustus 2018 \\
Dipublikasikan: \\
31 Agustus 2018 \\
\hline Kata Kunci: \\
hasil belajar, Biologi \\
Umum dan \\
Taksonomi \\
Invertebrata \\
\\
Keywords: \\
learning outcome, \\
general biology, \\
invertebrate \\
taxonomy
\end{tabular}

\begin{abstract}
Abstrak
Biologi umum mempelajari prinsip-prinsip biologi dan hubungannya dengan disiplin ilmu lainnya. Hasil belajar mahasiswa terhadap pemahaman Biologi Umum merupakan tolok ukur untuk mempelajari bidang ilmu biologi lainnya, salah satunya adalah Taksonomi Invertebrata. Oleh sebab itu untuk melihat hubungan tersebut, maka dilakukan penelitian yang bertujuan untuk mengetahui hubungan antara hasil belajar kompetensi pengetahuan Biologi Umum dengan hasil belajar kompetensi pengetahuan Taksonomi Invertebrata. Jenis penelitian deskriptif korelasi dengan partisipan sebanyak 123 orang mahasiswa. Sampel dipilih 60 orang mahasiswa secararandom sampling yang telah menuntaskan proses pembelajaran Biologi Umum dengan Taksonomi Invertebrata. Hasil belajar kompetensi pengetahuan Biologi Umum (variabel X) dan Taksonomi Invertebrata (variabel Y) dianalisis secara korelasional dengan rumus korelasi Pearson Product Moment. Hasil penelitian menunjukkan bahwa kompetensi pengetahuan mata kuliah Biologi Umum hanya 32,49\% menentukan kompetensi pengetahuanTaksonomi Invertebarata.

Abstract
General biology studies the principles of biology and its relationship
with other disciplines. Students learning outcomes on the
understanding of General Biology are a benchmark for studying other
fields of biology, one of which is Invertebrate Taxonomy. Therefore, a
research was conducted to find out the relationship between learning
outcomes of General Biology and the learning outcomes of Invertebrate
Taxonomy. This is a descriptive correlation study with 123 students as
participants. The sample of 60 students who have completed the
learning process of General Biology and Invertebrate Taxonomy are
selected by random sampling. Learning outcomes of General Biology
(variable X) and Invertebrate Taxonomy (variable Y) are analyzed
correlationally with the Pearson Product Moment correlation formula.
The results showed that the competence of General Biology course is
only 32.49\% determining the competence of Invertebarata Taxonomy.
\end{abstract}




\section{PENDAHULUAN}

Mata kuliah Taksonomi Invertebrata membahas prinsip-prinsip dasar taksonomi, nomenklatur dan klasifikasi hewan Invertebrata, terutama yang ada hubungannya dengan kehidupan manusia, klasifikasi contoh setiap ordo, perilaku, daerah penyebaran dan kepentingannya bagi manusia;Phylum Protozoa, Porifera, Coelenterata, Platyhelminthes,

Nemathelminthes, Molusca, Arthropoda dan Echinodermata. Prasyarat untuk dapat mengikuti mata kuliah Taksonomi Invertebrata adalah telah mengikuti mata kuliah Biologi Umum. Mata kuliah Biologi Umum dijadikan sebagai prasyarat karena mata kuliah Biologi Umum merupakan pengetahuan dasar bagi mata kuliah lain dalam bidang biologi, salah satunya Taksonomi Invertebrata.

Keberhasilan mahasiswa tahun akademik 2015 di salah satu perguruan tinggi ditandai dengan prestasi akademik yang dicapai yang ditunjukkan oleh indeks prestasi. Indeks prestasi akademik mahasiswa pada semester pertama tahun akademik 2015/2016, salah satunya ditentukan oleh nilai mata kuliah Biologi Umum. Sebaran nilai Biologi Umum mahasiswa semester pertama tahun akademik 2015/2016 sebagai berikut, nilai A sebanyak12,78\%, B sebanyak $68,42 \%$, C sebanyak $18,05 \%$ dan nilai D sebanyak $0,75 \%$. Sedangkan nilai mata kuliah Taksonomi Invertebrata menentukan indeks prestasi mahasiswa pada semester III. Sebaran nilai akhir Taksonomi Invertebrata adalah nilai A sebanyak $32,3 \%$, B sebanyak 50,0\%, C sebanyak $12,9 \%$ dan nilai D sebanyak $4,8 \%$.

Katagori nilai C dan D pada mata kuliah Taksonomi Invertebrata lebih dari $15 \%$. Hal itu berarti bahwa tingkat pemahaman mahasiswa terhadap materi Taksonomi Invertebrata masih kurang. Meskipun nilai $\mathrm{C}$ digolongkan lulus, tetapi mahasiswa yang mendapatkan nilai $\mathrm{C}$ cenderung akan memperbaiki pada semester berikutnya. Diperkirakan nilai Taksonomi Invertebrata ini terpengaruh akibat kurang pahamnya mahasiswa dengan mata kuliah Biologi Umum.

Studi korelasi ini dipilih karena memungkinkan pengukuran beberapa variabel dan saling hubungannya secara serentak dalam keadaan realistiknya, sesuai dengan yang disampaikan Suryabrata (2010: 82), tujuan dari studi 
korelasional ini untuk mendeteksi sejauh mana variasi-variasi pada suatu faktor berkaitan dengan variasi-variasi pada satu atau lebih faktor lain berdasarkan pada koefisien korelasi. Penelitian ini untuk mengidentifikasi apa sejalan dengan apa, tidak mesti menunjukkan saling hubungan yang bersifat kausal.

Berdasarkan latar belakang yang dikemukakan maka tujuan penelitian ini untuk mengetahui hubungan kompetensi pengetahuan Biologi Umum dengan Taksonomi Invertebrata dan seberapa besar hasil belajar Biologi Umum berkaitan dengan hasil belajar Taksonomi Invertebrata

\section{BAHAN DAN METODE}

Jenis penelitian ini adalah penelitian deskriptif korelasi, dilaksanakan pada Maret - Mei 2017 di STKIP PGRI Sumatera Barat. Menghubungkan hasil belajar kompetensi pengetahuan Biologi Umum dan Taksonomi Invertebrata mahasiswa Program Studi Pendidikan Biologi STKIP PGRI Sumatera Barat angkatan 2015. Partisipan pada penelitian ini sebanyak 123 orang mahasiswa Program Studi Pendidikan Biologi STKIP PGRI Sumatera Barat angkatan 2015. Penetapan 60 orang mahasiswa sebagai sampel (subjek penelitian) secara random sampling dengan pertimbangan hasil belajar tuntas pada kompetensi pengetahuan Biologi Umum dan kompetensi pengetahuan Taksonomi Invertebrata.

Data berupa data sekunder yaitu hasil belajar mahasiswa yang diperoleh dari Biro Administrasi Akademik STKIP PGRI Sumatera Barat berupa lembar nilai yang berisi nilai sikap dan tata nilai, keterampilan umum, keterampilan khusus dan pengetahuan. Nilai yang digunakan dalam penelitian adalah nilai kompetensi pengetahuan yang terdiri dari nilai ujian tengah semester dan nilai ujian akhir semester. Nilai hasil belajar yang sudah diperoleh kemudian ditentukan variabelnya, dimana Biologi Umum sebagai variabel $\mathrm{X}$ dan hasil belajar Taksonomi Invertebrata sebagai variabel $\mathrm{Y}$.

Uji normalitas kedua kelompok data (X dan Y) dengan Lilliefors mengacu pada Sudjana (1992: 466). Adapun langkah uji normalitas adalah sebagai berikut;Data dari yang terkecil sampai data yang terbesar diurutkan $\left(\mathrm{X}_{1}, \mathrm{X}_{2}, \mathrm{X}_{3}, \mathrm{X}_{4}, \ldots . \mathrm{X}_{\mathrm{n}}\right)$. Data $\mathrm{X}_{1}, \mathrm{X}_{2}, \mathrm{X}_{3}$, $\mathrm{X}_{4}, \ldots . \mathrm{X}_{\mathrm{n}}$ dijadikan bilangan baku dengan menggunakan rumus sebagai 
berikut: $Z_{1}=\frac{\bar{X}_{1-X}}{\mathrm{~s}}(\mathrm{X}$ dan $\mathrm{S}$ merupakan rata-rata dan simpangan baku sampel). Dengan menggunakan distribusi normal baku dihitung peluang, $F\left(Z_{1}\right)=P\left(Z \leq Z_{1}\right) . \quad$ Selanjutnya dihitung proporsi $\mathrm{Z}_{1}, \mathrm{Z}_{2}, \mathrm{Z}_{3}, \ldots . \mathrm{Z}_{\mathrm{n}}$ yang lebih kecil atau sama dengan $Z_{1}$ jika proporsi itu dinyatakan oleh $\mathrm{S}\left(\mathrm{Z}_{1}\right)$ maka: $\mathrm{S}\left(\mathrm{Z}_{1}\right)=$ $\frac{\text { banyaknya } Z_{1}, Z_{2, \ldots \ldots . . . y a n g} \leq Z_{n}}{n}$ Setelah itu hitunglah harga $\mathrm{F}\left(\mathrm{Z}_{1}\right)-\mathrm{S}\left(\mathrm{Z}_{2}\right)$, kemudian tentukan harga mutlaknya. Ambil harga yang paling besar diantara harga-harga mutlak selisih $\mathrm{F}\left(\mathrm{Z}_{1}\right)-\mathrm{S}\left(\mathrm{Z}_{2}\right)$, harga sebesar tersebut disebut $\mathrm{L}_{0}$. Pada taraf nyata 0,05 data berdistribusi normal jika $\mathrm{L}_{0} .<\mathrm{L}_{\text {tabel. }}$

Data hasil belajar kompetensi pengetahuan Biologi Umum dan Taksonomi Invertebrata dianalisis secara korelasional dengan rumus korelasi Pearson Product Moment, mengacu pada Usman dan Purnomo (2006: 197). Menurut Usman dan Purnomo (2006: 201), interpretasi dari nilai $r$ hitung yang diperoleh seperti pada Tabel 1.

Tabel 1. Interpretasi dari Nilai r Korelasi Pearson Product Moment

\begin{tabular}{cc}
\hline $\mathbf{r}_{\mathbf{x y}}$ & Interpretasi Hubungan \\
\hline 0,00 & Tidak berkorelasi \\
$0,01-0,20$ & Sangat rendah \\
$0,21-0,40$ & Rendah \\
$0,41-0,60$ & Agak rendah \\
$0,61-0,80$ & Cukup \\
$0,81-0,99$ & Tinggi \\
1,00 & Sangat tinggi \\
\hline
\end{tabular}

Rumus untuk mencari konstribusi variabel $\mathrm{X}$ terhadap variabel $\mathrm{Y}$ dengan menggunakan $\mathrm{KP}=\mathrm{r}^{2} \mathrm{x} 100 \%$, dimana $\mathrm{KP}$ adalah koefesien determinasi dan $\mathrm{r}^{2}$ adalah koefisien korelasi antara variabel X dan Y. Pengujian signifikasi korelasi atau keberartian koefisien korelasi dengan membandingkan nilai $r_{\text {hitung }}$ dengan nilai $r_{\text {tabel }}$ atau nilai $r$ kritis product moment.

\section{HASIL DAN PEMBAHASAN}

Hasil analisis data hasil belajar Biologi Umum $(\mathrm{X})$ dan hasil belajar Taksonomi Invertebrata (Y) disajikan pada Tabel 2. 
Tabel 2. Hasil Analisis Korelasi Antara Nilai Kompetensi Pengetahuan Biologi Umum dan Nilai Kompetensi Pengetahuan Taksonomi Invertebrata Mahasiswa Program Studi Pendidikan Biologi STKIP PGRI Sumatera Barat Tahun Angkatan 2015

\begin{tabular}{|c|c|c|}
\hline Parameter & $\begin{array}{l}\text { Hasil Perhitungan dan Rujukan } \\
\text { Tabel }\end{array}$ & Kriteria \\
\hline Uji Normalitas Nilai & $\mathrm{L}_{\mathrm{o}}=0,0665$ dan $\mathrm{L}_{\mathrm{t}}(\mathrm{n}=60)$ & $\mathrm{L}_{\mathrm{o}}<\mathrm{L}_{\mathrm{t}}=$ \\
\hline Kognitif Biologi umum & sig. $95 \%=0,0728$ & data berdistribusi normal \\
\hline Uji Normalitas Nilai & $\mathrm{L}_{\mathrm{o}}=0,0624$ dan $\mathrm{L}_{\mathrm{t}}(\mathrm{n}=60)$, & $\mathrm{L}_{\mathrm{o}}<\mathrm{L}_{\mathrm{t}}=$ \\
\hline Kognitif Taksonomi & sig. $95 \%=0,0728$ & data berdistribusi normal \\
\hline Invertebrata & & \\
\hline $\begin{array}{l}\text { Rerata Nilai Kognitif } \\
\text { Biologi Umum }\end{array}$ & 62,0 & Cukup \\
\hline $\begin{array}{l}\text { Rerata Nilai Kognitif } \\
\text { Taksonomi Invertebrata }\end{array}$ & 59,5 & Cukup \\
\hline Nilai $r$ & $\begin{array}{c}r_{\text {hitung }}=0,57 \text { dan } r_{\text {tabel }}(n=60), \\
\text { sig. } 95 \%=0,211\end{array}$ & $\begin{array}{l}\text { korelasi linier positif tetapi } \\
\text { agak rendah,dan } r_{\text {hitung }}>r_{\text {tabel }} \\
\quad=\text { korelasi signifikan }\end{array}$ \\
\hline Koofisien determinasi & $r^{2} \times 100 \%=32,49 \%$ & $\begin{array}{c}\text { Sumbangan X terhadap Y } \\
\text { rendah }\end{array}$ \\
\hline
\end{tabular}

Berdasarkan Tabel 2, antara hasil belajar kompetensi pengetahuan Biologi Umum dengan Taksonomi Invertebrata terdapat hubungan positif dan signifikan. Kompetensi pengetahuan mata kuliah Biologi Umum tidak mutlak menentukan hasil belajar pada mata kuliah Taksonomi Invertebrata. Koofisien determinasi hanya $32,49 \%$, itu berarti bahwa kompetensi pengetahuan mata kuliah Biologi Umum merupakan salah satu faktor penentu hasil belajar atau kompetensi pengetahuan Taksonomi Invertebrata. Pengetahuan dasar tentang ruang lingkup biologi dan hubungannya dengan ilmu lain; konsep sel, jaringan, dan organ; dan sejarah klasifikasi dan dasar-dasar klasifikasi merupakan pengetahuan dasar yang telah dipelajari di mata kuliah Biologi Umum. Pengetahuan dasar yang dipelajari pada mata kuliah Biologi Umum tidak secara langsung menentukan keberhasilan belajar mata kuliah Taksonomi Invertebrata. Hal itu berarti hasil belajar kompetensi pengetahuan Taksonomi Invertebrata juga ditentukan oleh faktor lain baik faktor internal maupun faktor eksternal.

Secara garis besar faktor-faktor yangmempengaruhi hasil belajar dapat 
dibedakan menjadi dua jenis yaitu: (a) Faktor-faktor yang bersumber dari dalam diri manusia, faktor ini dapat diklasifikasikan menjadi dua, yakni faktor biologis dan faktor psikologis. Faktor biologis antara lain usia, kematangan dan kesehatan. Sedangkan faktor psikologis adalah kelelahan, suasana hati, motivasi,minat dan kebiasaan belajar. (b) Faktor-faktor yang bersumber dari luar diri manusia, faktor ini diklasifikasikan menjadi dua yakni faktor manusia dan faktor non manusia seperti alam, benda, hewan, dan lingkungan fisik (Sanjaya, 2011: 131).

Hasil penelitian ini relevan dengan hasil penelitian beberapa orang peneliti yang mengkorelasikan nilai mata kuliah di beberapa fakultas lainnya, yaitu : (1) Ruswinda (2013) bahwa, ada hubungan positif dan kuat antara kemampuan mahasiswa pada mata kuliah Telaah Kurikulum Biologi dengan Pengembangan Program Pembelajaran Biologi mahasiswa angkatan 2009 di FKIP Universitas Riau, (2) Silaban (2014), ada hubungan positif dan signifikan antara penguasaan Konsep Fisika dan Kreativitas dengan kemampuan memecahkan masalah pada materi pokok Listrik Statis,

Sunaryaningsih (2016), ditemukan hubungan yang positif dan signifikan antara penguasaan Teori Dasar-Dasar Elektronika dengan penguasaan Pengukuran Komponen Elektronika dalam mengingkatkan hasil belajar pada materi Memahami Dasar-Dasar Elektronika siswa kelas X SMKN 1 Geneng, (4) Sugeng (2016), ada hubungan positif Kemampuan Matematika dan Fisika terhadap Prestasi Belajar mahasiswa Teknik Elektro D3 Unisma. Selain itu, berkaitan dengan faktor internal dari peserta didik, penelitian Chania (2016), diperoleh hasil tidak ada hubungan yang signifikan antara Gaya Belajar dan Hasil Belajar Biologi siswa kelas X SMAN 2 Sungai Tarab Kabupaten Tanah Datar, dan penelitian Hidayat (2013), terdapat hubungan Regulasi Diri dengan Prestasi Belajar Kalkulus II ditinjau dari aspek metagognisi, motivasi dan perilaku.

Sehubungan dengan hasil belajar kompetensi pengetahuan dari nilai UTS dan UAS mata kuliah Biologi Umum pada kategori cukup, diduga karena perubahan kurikulum dari kurikulum sekolah menengah ke kurikulum perguruan tinggi. Deskripsi kualifikasi 
dari Kerangka Kualifikasi Nasional Indonesia (KKNI) yang tercantum pada Peraturan Presiden Republik Indonesia Nomor 8 Tahun 2012, dimana capaian pembelajaran mahasiswa sebagai seorang sarjana (level 6) adalah: menguasai konsep teoritis bidang pengetahuan dan keterampilan tertentu secara umum dan konsep teoritis bagian khusus dalam bidang pengetahuan dan keterampilan tersebut secara mendalam. Sedangkan capaian pembelajaran untuk lulusan SMA (level 2) adalah memiliki pengetahuan operasional dasar dan pengetahuan faktual bidang kerja yang spesifik, sehingga mampu memilih pemecahan yang tersedia terhadap masalah yang lazim timbul.

Aplikasi untuk mewujudkan capaian tersebut tentu berbeda. Salah satu contohnya adalah ketentuan sistem kredit semester dan harus mampu memanfaatkan semua sumber dan media belajar yang ada. Berdasarkan hasil observasi tugas-tugas yang diberikan dosen menuntut mahasiswa untuk mencari banyak literatur yang relevan dan mutakhir dan mengembangkan pola pikirnya sendiri guna penyelesaiannya secara efektif.
Hasil belajar Taksonomi Invertebrata yang juga berada pada level cukup diduga karena kedalaman materi yang harus dikuasai, kemampuan untuk mengidentifikasi hewan dalam beberapa kelas, kegiatan praktikum dan serta adanya kegiatan studi langsung ke lapangan. Menurut Wulandari (2007), hakikat biologi tidak hanya berupa teori, hafalan dan pemahaman akan konsep saja, tetapi juga berupa proses penerapan dan bahkan penemuan, maka dalam pembelajaran- nya harus melibatkan siswa secara aktif untuk berinteraksi dengan objek konkret.

Tingkat keberhasilan dalam proses pendidikan juga dipengaruhi oleh banyak faktor yang secara garis besar faktor-faktor tersebut dapat dikelompokkan menjadi dua, yaitu :(1) Faktor intelektual adalah kemampuan seseorang yang diperlihatkan melalui kecerdasan dan kepandaiannya dalam berpikir dan berbuat, misalnya bakat, kapasitas belajar, kecerdasandan hasil belajar yang dicapai dalam hal ini adalah jumlah nilai ujian nasional SLTA, (2) Faktor non-intelektual adalah segala kondisi dari dalam dan luar dirinya atau lingkungan sekitar, yang terkait dengan diri seorang dalam 
mempengaruhi kemampuan berpikir dan bertindak, misalnya masalah belajar, jenis kelamin, karir, sosial, emosional, jalur masuk perguruan tinggi, keuangan, asal daerah, keluarga, pemakaian waktu luang, organisasi, sahabat, metode belajar, dan lingkungan (Hildayati, 2002).

Setiap proses pembelajaran, keberhasilannya diukur dari seberapa jauh hasil belajar yang dicapai, disamping diukur dari segi prosesnya. Burton (1952 dalam Lufri dkk., 2007) memberi argumen bahwa, hasil belajar merupakan pola-pola perbuatan, nilainilai, pengertian-pengertian, sikap, apresiasi, kemampuan dan keterampilan. Hasil belajar itu lambat laun dipersatukan menjadi kepribadian dengan kecepatan yang berbeda-beda. Hasil belajar yang telah dicapai bersifat kompleks dan dapat beradaptasi (adabtable) atau tidak sederhana dan tidak statis. Mudjiono dan Dimyati (2006) memberikan pendapat bahwa, hasil belajar berupa kapabilitas. Setelah belajar orang memiliki keterampilan, pengetahuan, sikap dan nilai. Timbulnya kapabilitas dari stimulasi yang berasal dari lingkungan dan proses kognitif yang dilakukan. Dengan demikian hasil belajar adalah seperangkat proses kognitif yang mengubah sifat stimulasi lingkungan, melewati pengolahan informasi menjadi kapabilitas baru.

\section{SIMPULAN}

Ada hubungan positif tetapi agak rendah dan signifikan antara hasil belajar Biologi Umum dengan hasil belajar Taksonomi Invertebrata mahasiswa. Kompetensi pengetahuan Taksonomi Invertebrata ditentukan oleh kompetensi pengetahuan Biologi Umum sebesar $32,49 \%$.

\section{DAFTAR PUSTAKA}

Anonimus, 2015 b. Permenristekdikti RI Nomor 44 Tahun 2015.

Anonimus. 2015 a. Buku Pedoman Akademik Penyelenggaraan Pendidikan Tahun Akademik 2015/2016. STKIP PGRI Sumatera Barat, Padang.

Chania, Y., M. Haviz dan Dewi S. 2016. Hubungan Gaya Belajar Dengan Hasil Belajar Siswa Pada Pembelajaran Biologi Kelas X SMAN 2 Sungai Tarab Kabupaten Tanah Datar. Jurnal Saintek. 8 (1): 77-84 IAIN Batusangkar.

Hidayat, AF. 2013. Hubungan Regulasi Diri Dengan Prestasi Belajar Kalkulus II Ditinjau Dari Aspek Metagognisi, Motivasi dan Perilaku. Jurnal Elektronik Untad. ac.id. 
Hildayati, M. 2002. Penelusuran Faktor-Faktor Yang Mempengaruhi Prestasi Akademik Mahasiswa Semester I Universitas IBN Khaldum Bogor. Skripsi Jurusan Statistika MIPA IPB Bogor.

Jihad, A., dan Abdul H. 2012. Evaluasi Pembelajaran. Yogyakarta: Multi Pressindo.

Lufri, AY., Yunus dan Sudirman. 2007. Strategi Pembelajaran Biologi. Jurusan Biologi FMIPA UNP. Padang

Mudjiono dan Dimyati 2006. Belajar dan Pembelajaran. Jakarta: Rineka Cipta.

Ruswinda, F., Evi S., dan Yustini Y. 2013. Hubungan Antara Kemampuan Mahasiswa Pada MataKuliah Telaah Kurikulum Biologi Dengan Pengembangan Program Pembelajaran Biologi (P3B) Mahasiswa Angkatan 2009 Program Studi Pendidikan Biologi FKIP Universitas Riau. Repository. Unri.ac.id.

Silaban, B. 2014. Hubungan Antara Penguasaan Konsep Fisika dan Kreativitas Dengan Kemampuan Memecahkan Masalah Pada Materi Pokok Listrik Statis.
Jurnal Penelitian Bidang Pendidikan. Vol. 20 (I): 65-75.

Sudjana. 1992. Metoda Statistika.

Edisi Kelima. Bandung: Tarsito.

Sugeng. 2016. Korelasi Kemampuan Matematika dan Fisika Terhadap Prestasi Belajar Mahasiswa Teknik Elektro D3 Unisma. Journal of Electrical and Electronic. Vol. 1 Nomor 1.

Surnaryaningsih, Ina dan Dedi K. 2016. Hubungan Antara Penguasaan Teori Dasar-Dasar Elektronika Dengan Penguasaan Pengukuran Komponen Elektronika Dalam Meningkatkan Hasil Belajar Pada Materi Memahami Dasar-Dasar Elektronika Siswa Kelas X SMKN Geneng. Jurnal Pendidikan Teknik Elektro (Jupiter). Vol. 1 Nomor 1. Maret.

Suryabrata, S. 2010. Metodologi Penelitian. Jakarta: RajaGrafindo Persada.

Usman, H., dan Purnomo SS. 2006. Pengantar Statistika. Edisi Kedua. Jakarta: Bumi Aksara

Zainul, A., dan Noehi N. 2005. Penilaian Hasil Belajar. PAUPPAI. Direktorat Jenderal Pendidikan Tinggi Departemen Pendidikan Nasional, Jakarta. 